Acta Regionalia et Environmentalica 1

Nitra, Slovaca Universitas Agriculturae Nitriae, 2018, pp. 22-27

\title{
FINANCING OF GRASSLAND HABITATS IN THE SLOVAK REPUBLIC IN 2010-2016
}

\author{
Ivan HOLÚBEK*, Peter HRIC, Peter KOVÁR, Andrea BOHÁČIKOVÁ \\ Slovak University of Agriculture in Nitra, Slovak Republic
}

\begin{abstract}
The grasslands in the Slovak Republic are divided into 7 categories that have different way and conditions of management to protect and maintain them. From the area of 1,239,777 hectares of habitats in SR and payments per hectare, we calculated the amount of financial support that represents 130,265,701 € for the A-G habitats in 2010-2016. Based on the data about potential use of grassland habitats in livestock feeding (mountain meadows and alluvial meadows), the production potential of $C$ $3.12 \mathrm{t}^{\text {h ha }}{ }^{-1}$ biotope $\mathrm{E} 4.25 \mathrm{t}^{\text {h.ha }}{ }^{-1}$ of dry matter was calculated, as a result of 5-years long experiment of the Department of Grassland Ecosystems and Forage Crops of SUA in Nitra. We calculated the direct costs for the production of hay dry matter, which reached $116.78 €$.ha-1 in the meadows, and $71.11 €$.ha $^{-1}$ in valleys. Direct costs per 1 hectare of hay dry production are with a support covered on $111.0 \%$ of mountain meadows and $74 \%$ of meadows. The annual value of ecosystem services of grassland habitats reached $579,789,008 €$. Subsidies for permanent grassland habitats stimulate the economy of agricultural subjects and protect the biodiversity of permanent grasslands.
\end{abstract}

Keywords: direct costs, grassland habitats, supportive policy

Slovakia has a wide variety of natural conditions associated with the rich species diversity of flora and fauna. In our conditions, to the important species of flora belong permanent grasslands (PG) - meadows and pastures (Holúbek et al., 2007). They occur from the lowlands to the subalpine zone, from wet to dry locations (Krajčovič et al., 1968). The average area of grasslands used in 2011-2015 is 515,652 ha (Green Report, 2016).

As a result of the reduction of amount of ruminant livestock after 1990, we record 320 thousand hectares of permanent grassland not used for livestock feeding. This state causes the rise of non-woody vegetation (NWV), the start of the soils and consequently deterioration of the quality of the agricultural landscape (Midriak et al., 2011).

Their quality, as a habitat for plant communities and species, is heavily influenced by the way and intensity of management (Ružičková and Kalivoda, 2007). In the conventional management system and in the currently preferred low-input system, they have many benefits and are therefore considered to be highly perspective cultures (Holúbek et al., 2014). As a part of the agricultural system and countryside, they have economic value in production and contribute to SET group (rural interests) (Lehman and Hediger, 2004). In the Czechoslovak conditions, the research of authors Krajčovič et al. (1968), Rychnovská et al. (1985), Holúbek et al. (2007) was beneficial for the theory and practice of meadows and pastures. In the recent years, the supporting policy has significantly contributed to the sustainability of biodiversity, particularly in areas of European importance and in areas of high natural value. Supporting policy has crucial importance for the income stability of farms operating in production and less-favoured areas. Subsidies and supports, including habitat protection support, stimulate the economy of companies, the investment process and have also an effect on efficiency through reducing costs and increasing labour productivity (Chrastinová et al., 2010, 2013).

The worldwide project Milenium Ecosystem Assesment (MA, 2005) characterizes benefits as ecosystem services. The extent and quality of ecosystem services depends on the nature. Biodiversity and the health of ecosystems are basic requirements to be able to gain ecosystem services of nature. In September 2016, the $26^{\text {th }}$ Meeting of the European Lieutenant Federation in Trondheim (Norway) took place. The motto of the scientific conference was the multifunctional role of grassland in European bio-economics. A significant contribution in this context is presented by Plantereux et al. (2016). Based on these findings, as well as the research activities of Slovak grassland and pasture, we evaluate the potential effects of grassland habitats, including utilities ecosystem services in this paper.

\section{Material and methods}

\section{Data and methodology}

Currently, biotopes of semi-natural and natural grasslands can be found at different stages of development that have been created by long-term grazing and secondary succession after grazing. For the favourable state of habitats, management of grazing and mowing is necessary. Otherwise, the habitats in the process of succession can change and thus get into an unfavourable state. In order to provide support, it is necessary for farmers to accept the 
principles, and conditions of the grasslands management. The management of selected areas of semi-natural and natural grasslands aims to contribute to sustainability of biodiversity of major areas of European significance and areas of high natural value.

To the semi-natural and natural permanent grasslands covered by the supporting policy belong (codes of the relevant habitat types according the Habitats Catalogue in Slovakia are listed in the brackets):

A. Thermophilic and xerophilous grasslands $(\operatorname{Tr} 1, \operatorname{Tr} 2, \operatorname{Tr} 3$, $\operatorname{Tr} 4, \operatorname{Tr} 5)$.

B. Mesophile permanent grasslands (Lk1, Lk3, Tr8b).

C. Mountain meadows (Lk2).

D. Hydrophilous vegetation of lower areas (Lk7, Lk9, Lk10, Lk11, S11, S14).

E. Lowland alluvial meadows (Lk8).

F. Hydrophilous vegetation of higher areas, peat and molinia meadows (Lk4, Lk5, Lk6, Ra3, Ra5, Ra6, Ra7, S12).

G. High mountain grasslands (Tr8a, A11, A13, A16, A18).

Providing the support for protection of biotopes of semi-natural and natural grasslands is limited by compliance with the management conditions of individual types of grasslands.

\section{Conditions for the management of grasslands:}

- Fertilization allowed only organic, for types B and C.

- Limited to $50 \mathrm{~kg} \cdot \mathrm{ha}^{-1} \mathrm{~N}$ each second year.

- Prohibition of chemistry except for the spot use approved by the ÚKSÚP.

- Deadline for mowing till July 15, (professional organization may edit date).

- The grasslands are cut from the centre towards the edges.

- Type F (Hydrophilous vegetation of higher areas) are cut only manually or using light mechanization.

- In type $\mathrm{F}$ is passion completely excluded, in type $\mathrm{C}$ and type $E$ is allowed only after cutting.

- Corralling is allowed only in Type B (mesophile meadows), and in type $\mathrm{G}$ stallions of livestock can be also permanent, with the permission of a professional organization.

- Prohibition of fenced pasture.

- Allowed load (0.3-1.0 VDJ).
- Types A, G are cut maximum once, others can be cut twice.

- Gentle cohorting for 10 meters square, daily transshipment of pens.

- Careful fencing 1VDJ to 10 metres square, daily changing of corrals for animals), shepherd's supervision.

- Prohibition of additional seeding, draining and mulching.

From the information about habitats of the SR and the payments, the amount of supports is calculated (Table 1).

\section{Methods of determining support}

The amount of support is aimed to compensate the financial loss from reduced production and additional costs connected with the special conditions for grassland $C C(G A E+M R)$ and national legislation. This difference is reduced by the costs saved by respecting the conditions for the farming. Long-term research of semi-natural and natural PG including biotopes C - Mountain meadows (Lk2), and E - Low alluvial meadows (Lk8) respecting the conditions of management have enabled us to assess the production of hay dry matter, quality indicators and the cost of hay dry production in a double-scaled system of utilization.

Production of hay dry matter was obtained as a part of research project of the Department of Grass Ecosystems and Fodder Plants (Holúbek et al., 2007).

The cost of dry matter production per 1 hectare of area was calculated according to the technological and economic parameters used by the Research Institute of Agricultural Technology in Prague-Ruzyně (http://www.vuzt.cz/index. php?|=A35).

Direct costs of production of hay dry matter were exchanged at the current exchange rate from 31. 3. 2017 ( $1 €=27.030 \mathrm{CZK}$ ). Costs of cutting have been converted according to the used mower TK $50 \mathrm{~kW}$ (rotary mower 2.5) at the price of $16.02 €$ ha $^{-1}$, turning and hay-bending with a set TK $50 \mathrm{~kW}$ (tiller $6 \mathrm{~m}$ ) at a price of $11.39 € . \mathrm{ha}^{-1}$, collecting of hay with trailer TK $50 \mathrm{~kW}$ (collector semitrailer $30 \mathrm{~m}^{3}$ ) at the price of $4.62 €$.ha $^{-1}$, transport of hay dry matter into hay-loft TK $50 \mathrm{~kW}$ (trailer 5t) at a price of $1.92 € . \mathrm{ha}^{-1}$, pressing hay into the parchment packages TK $90 \mathrm{~kW}$ (parquet press $80 \times 90$ $\mathrm{cm})$ at the price $41.16 € \cdot \mathrm{ha}^{-1}$.

Table 1 Financial support

\begin{tabular}{|c|c|c|}
\hline Type & Protection of grassland habitats & Payment in $€$. ha $^{-1}$ \\
\hline A & Thermophilic and xerophilous grasslands & 89.95 \\
\hline B & Mesophile permanent grasslands & 74.57 \\
\hline C & Mountain meadows & 128.88 \\
\hline D & Hydrophilous vegetation of lower areas & 74.57 \\
\hline $\mathbf{E}$ & Lowland alluvial meadows & 52.73 \\
\hline $\mathbf{F}$ & Hydrophilous vegetation of higher areas & 158.60 \\
\hline G & Peat and molinia meadows & 150.72 \\
\hline
\end{tabular}

Source: PPA BA, 2016 


\section{Results and discussion}

\section{Financing of habitats of permanent grassland}

A significant part of the Common Agricultural Policy (CAP) is the support policy for agriculture and subsidies aimed to help farmers to achieve prosperity. Subsidies are tools to implement the objectives of a particular policy. The choice of proper tools and their combination should be done based on the revised strategy and objectives, the knowledge of the environment and the overall economic situation of the country (Bečvarová, 2008; Ďuricová, 2014).

The application of the systems of pratotechnology in the assessed areas of habitats of natural and semi-natural permanent grasslands is aimed to contribute to the preservation of biodiversity, especially in areas of European importance and areas with high added value. Biodiversity has a significant impact on quality of life, ensures ecological functions and is the basis for food security.

In order to protect selected PG habitats, a project focusing on the inventory of PG in the SR (Daphne with the Royal Dutch Company) was implemented in 1998. As a result of this project, the Agroenvironmental Program for the Slovak Republic (Kováč and Sabo, 2001) was elaborated, after which the catalogue "Favourable state of habitats and species of European significance, Manual for Territory Care Programs Natura 2000" was created (Polák and Saksa, 2001). In this publication, Valachovič et al. (2005) prepared a management measure to sustain the favourable state of European (non-forest) habitat types. For the financing of semi-natural and natural habitats of PG, new types of habitats were defined in the Rural Development Plan RDP (A-G). In relation to the discussed issue, the basic role in the field of nature protection is the creation of a coherent European network of protected areas (Natura 2000). The objective of networking is to maintain or improve the favourable status of habitats of European significance. Each Member State is required to prepare the necessary plans to pursue this objective. According to the legislation of the Slovak Republic, these plans are called "Care Programmes." In this context, the definition of favourable state for each type of biotope and each species was formulated in the SR. During the process of this task, the way of assessing defined habitats and species as well as general principles for habitat types were created (Habitat Catalogue, 2005). By the accession of Slovak Republic to the EU in 2004, we committed to adopt the regulations of the Common Agricultural Policy.

Permanent grasslands in the SR are divided into 7 categories in our assessment and are covered by a supportive policy. Financial support for the protection of PG habitats is limited by the management conditions. The amounts of support were calculated from the hectare areas of the grasslands in SR during the years 2010-2016 and information about payments provided by the APA. The results are shown in Table 2.

Table 2 Payment on the area (ha) of PG habitats in years in thousands ( $€$ )

\begin{tabular}{|l||c|c|c|c|c|c|c|c|}
\hline \multicolumn{2}{|l||}{ Year } & \multicolumn{2}{c|}{$\mathbf{2 0 1 0}$} & \multicolumn{2}{c|}{$\mathbf{2 0 1 1}$} & \multicolumn{2}{c|}{$\mathbf{2 0 1 2}$} & \multicolumn{2}{c|}{$\mathbf{2 0 1 3}$} \\
\hline Habitat of PG & area in ha & $\boldsymbol{\epsilon}$ & area in ha & $\boldsymbol{\epsilon}$ & area in ha & $\boldsymbol{\epsilon}$ & area in ha & $\boldsymbol{\epsilon}$ \\
\hline \hline A & 5,766 & 518,652 & 5,640 & 507,318 & 5,623 & 505,789 & 5,240 & 471,338 \\
\hline B & 147,922 & $11,030,544$ & 147,794 & $11,020,999$ & 147,135 & $10,971,857$ & 141,485 & $10,550,536$ \\
\hline C & 2,594 & 334,315 & 2,583 & 332,897 & 2,583 & 332,897 & 2,568 & 330,964 \\
\hline D & 8,083 & 602,749 & 8,341 & 621,988 & 8,333 & 621,392 & 8,216 & 612,667 \\
\hline E & 2,882 & 151,968 & 2,628 & 138,574 & 2,628 & 138,574 & 2,665 & 140,525 \\
\hline F & 4,343 & 688,887 & 4,569 & 724,735 & 4,532 & 718,866 & 4,415 & 700,307 \\
\hline G & 3,476 & 523,903 & 3,482 & 524,807 & 3,458 & 521,190 & 3,317 & 499,938 \\
\hline Sum & 175,066 & $13,851,017$ & 175,037 & $13,871,318$ & 174,292 & $13,810,565$ & 167,906 & $13,306,276$ \\
\hline
\end{tabular}

\begin{tabular}{|l|c|c|c|c|c|c|c|c|}
\hline Year & \multicolumn{2}{|c|}{2014} & \multicolumn{2}{c|}{2015} & \multicolumn{2}{c|}{2016} & \multicolumn{2}{c|}{$2010-2016$} \\
\hline Habitat of PG & area in ha & $€$ & area in ha & $€$ & area in ha & $€$ & area in ha & $€$ \\
\hline \hline A & 5,153 & 463,512 & 6,539 & 588,210 & 7,712 & 693,679 & 41,673 & $3,748,498$ \\
\hline B & 140,079 & $10,445,691$ & 154,619 & $26,991,861$ & 164,841 & $28,776,339$ & $1,043,875$ & $109,817,827$ \\
\hline C & 2,562 & 330,191 & 3,409 & 439,412 & 3,321 & 427,958 & 19,620 & $2,528,633$ \\
\hline D & 8,115 & 605,136 & 9,694 & 722,846 & 9,244 & 689,331 & 60,026 & $4,476,109$ \\
\hline E & 2,643 & 139,365 & 2,528 & 133,313 & 2,383 & 125,661 & 18,357 & 967,982 \\
\hline F & 4,368 & 692,852 & 4,882 & 774,220 & 4,850 & 769,228 & 31,959 & $5,069,095$ \\
\hline G & 3,283 & 494,814 & 3,705 & 558,400 & 3,546 & 534,505 & 24,267 & $3,657,557$ \\
\hline Sum & 166,203 & $13,171,561$ & 185,376 & $30,208,262$ & 195,897 & $32,016,700$ & $1,239,777$ & $130,265,701$ \\
\hline
\end{tabular}

Source: APA, own processing 
In 2010-2016, the total area of the PG habitats $(A-G)$ reached $1,239,777$ ha with the total support of $130,265,701 €$. In the 2010-2016 average, the highest yield of 149,125 hectares, with the support of $15,568,826 €$ reached the habitat $B$ (Mesophile permanent grasslands). The smallest area of 2,622 ha with the support of $138,285 €$ was reached by the biotope $\mathrm{E}$ (lowland alluvial meadows). Comparing the areas of habitats ( $A$ and $G$ ) in the years 2010 2016 , there was found out an increase from 175,066 ha to 195,897 ha, which represents an increase by 20,831 ha, resp. $8.9 \%$. In 2016, the area of PG habitats in the SR reached 195,897 ha.

In order to make a comprehensive assessment of grassland habitats as well as used PGs in other years in the SR, we also evaluated ecosystem services - the benefits provided to society by nature. The methodology of Honigová et al. (2012) was selected. The value of ecosystem services of habitats (A-G) for 2010-2016 reached the amount $4,058,523,057 €$, annually $579,789,008.1 €$ (Table 3 ).

\section{Assessment of production costs of hay dry matter}

Long-term research of semi-natural grasslands habitats - C mountain meadow (Lk2) and lowland alluvial meadows (Lk8), respecting "Management conditions of PG", enabled the proper assessment of production, quality and cost of hay dry matter production in double-cutting system of use.

C - mountain meadow (Lk2), Association LolioCynosuretum typicum. The grassland is a mesohygrotic community, taxonomically characteristic by low share of clovers, high share of grass, and medium share of meadow herbs. The Community is presented by 28 taxa: Agrostis tenuis Sibth., Anthoxanthum odoratum L., Cynosurus cristatum L., Dactylis glomerata L., Festuca pratensis Huds., Festuca rubra L., Lolium perenne L., Nardus stricta L., Poa pratensis L., Tristeum flavescens (L.) Beauv., Trifolium pratense L., Trifolium repens L., Vicia cracca L., Acetosa pratensis Mill., Achillea millefolium L., Alchemilla monticola Opitz., Campanula patula L., Carum carvi L., Cerastium arvense L., Crepis bienis L., Cruciata glabra Ehrend., Daucus carota L., Euphrasia rostkoviana Hayne., Hypericum maculatum Cranz., Knautia arvensis (L.), Coulter, Leontodon hispidus L., Plantago lanceolata L., Plantago media L., Potentilla reptans L., Prunella vulgaris L., Ranunculus acris L., Rhinanthus minor L., Taraxacum officinale Weber in Wiggers a Veronica chamaedrys L. (Vozár, 2009).
E-lowlandalluvialmeadow(Lk8), AssociationFestucetum pratense. The grassland is represented by a varied floristic composition with dominant taxa: Festuca rubra L. ssp. Fallax Hack., Anthoxanthum odoradum L., Alopecurus pratensis L., Arrhenatherum elatius Presl. a Dactylis glomerata L. A high share of clover has been reported in severeal species. They have been greatly expanded in Lotus cornitulacus L., Trifolium pratense et repens L., Lathyrus pratensis L., localy Vicia cracca L. a Medicago lupulina L. From the agro-botanic group of other herbs had a high share Colchicum autumnale L., Equisetum pratense Ehrh., Rumex acetosa L., Centaurea jacea L., Leontodon hispidus er autumnale L., Ranunculus acer L., Galium sp., Plantago lanceolata L. and other species rarely expanded, or only sporadically. Original herbage was very rich for the meadow herbs, which dominated in both cuttings (Lichner et al., 1971).

The main variables for the cost calculation in the production of hay dry matter are the cost of plants treatment and costs of harvesting. The cost analysis was carried out according to the technological and economic parameters for the forage production used by the Research Institute of Agricultural Technology in Prague (see methodology). The results are shown in Table 4. Assessed habitats, assuming their production use for livestock feed, are presented without any inputs by relatively high yields. A higher production potential, $8.7 \mathrm{~m} 3$ of dry matter, is seen in the habitat lowland meadows. The analysis of cuttings shows a higher production of hay dry matter in the first cutting 2.0-2.2 t.ha ${ }^{-1}$. In the second cutting, the average yield of hay dry matter reaches from $1.2 \mathrm{t}^{-h a^{-1}}$ to $1.9 \mathrm{t}^{-h a^{-1}}$. In the production of hay dry matter, we used the same technological processes in mountain meadows, as well as in valley meadows, with the exception of harvesting methods. The results show higher costs for the production of hay dry matter by pressing $\left(54.98 € . h^{-1}\right)$, lower in the production of dry matter with a semitrailer $\left(9.24 € . h^{-1}\right)$. The different harvesting methods were subsequently reflected in the total direct costs per hectare, and reached $116.78 €$. ha $^{-1}$ in mountain meadows, and $71.11 €^{-h^{-1}}$ in lowland (valley) meadows. The costs of production of hay dry matter per hectare in mountain meadows are covered by the support policy at $110.30 \%$; however, in the valley meadows it is only $74.15 \%$ coverage. Supporting policy has crucial importance for the income stability of farms operating in production

Table 3 Potential performance of PG habitats (ecosystem services) in $€$ in 2010-2016

\begin{tabular}{|l|c|c|c|c|}
\hline Habitats of permanent grassland & Area in ha & $\mathbf{\epsilon . h a - 1}$ & $\mathbf{2 0 1 0 - 2 0 1 6}$ & Per 1 year \\
\hline \hline Thermophilic and xerophilous grasslands & 41,673 & $2,584.76$ & $107,714,703.50$ & $15,387,814.78$ \\
\hline Mesophile permanent grasslands & $1,043,875$ & $3,224.37$ & $3,365,839,234$ & $480,834,176.30$ \\
\hline Mountain meadows & 19,620 & $1,614.76$ & $31,681,591.20$ & $4,525,941.60$ \\
\hline Hydrophilous vegetation of lower areas & 60,026 & $4,497.91$ & $269,991,545.70$ & $38,570,220.81$ \\
\hline Lowland alluvial meadows & 18,357 & $4,180.64$ & $76,744,008.48$ & $10,963,429.78$ \\
\hline Hydrophilous vegetation of higher areas & 31,959 & $4,338.50$ & $138,654,121.50$ & $19,807,731.64$ \\
\hline Alpine grasslands & 24,267 & $2,797.95$ & $67,897,852.65$ & $9,699,693.23$ \\
\hline Total & $1,239,777$ & - & $4,058,523,057$ & $579,789,008.10$ \\
\hline
\end{tabular}

Source: APA, Honigová et al., 2012, own processing 
Table 4 Direct costs (DC) of hay dry matter production of PG habitats in $€$.ha ${ }^{-1}$ - simulation for practice

\begin{tabular}{|l||c|c|c|c|}
\hline Indicator & Mountain meadows & $\begin{array}{c}\text { Structure od DC } \\
\text { per ha in \% }\end{array}$ & $\begin{array}{c}\text { Lowland (valley) } \\
\text { meadows }\end{array}$ & $\begin{array}{c}\text { Structure od DC } \\
\text { per ha in \% }\end{array}$ \\
\hline \hline Dry matter in t.ha ${ }^{-1}$ & 3.12 & - & 4.25 & - \\
\hline Cutting & 36.07 & 30.88 & 36.07 & 51.56 \\
\hline Turning + collecting & 22.78 & 19.49 & 22.77 & 32.02 \\
\hline Hay pressing (balers) & 54.91 & 47.02 & 0 & 0 \\
\hline $\begin{array}{l}\text { Hay harvesting with } \\
\text { the collecting semitrailer }\end{array}$ & 0 & 0 & 9.24 & 12.99 \\
\hline Transport & 3.03 & 2.59 & 3.03 & 4.26 \\
\hline Sum & 116.78 & 100 & 71.11 & 100 \\
\hline Costs per 1 tone & 37.43 & - & 16.73 & - \\
\hline
\end{tabular}

Source: VúZT Praha-Ruzyňe, 2015, own processing

and less-favoured areas. Subsidies and supports, including habitat protection support, stimulate the economy of companies, the investment process and have also an effect on efficiency through reducing costs and increasing labour productivity (Chrastinová et al., 2013)

\section{Conclusion}

The supportive policy of habitats of natural and semi-natural permanent grasslands (A-G) was analysed in cooperation with the APA. From the achieved results the following conclusions can be summarized.

In the evaluated years 2010-2016 the total area of PG habitats reached $1,239,777$ ha in the SR, with the total support of $130,265,701 €$. In the 2010-2016 average, a maximum of 149.125 hectares with a support of 1,568 , $826 €$ was presented for the biotope $B$ (Mesophile permanent grasslands); the smallest area of 2,622 ha with support of $128,283 €$ was reached in the biotope $E$ (lowland alluvial meadows). In the double-cutting system of habitat use, the production of dry matter mountain and valley meadows can be exploited in animal nutrition. Direct costs of production of mountain hay dry matter reached $116.78 €$. ha $^{-1}$, in valley meadows only $71.11 €$. ha $^{-1}$.

Financial supports of supportive policy covered $74.15 \%$ of direct costs of producing dry matter in lowland meadows and $110.36 \%$ in mountain meadows. The value of ecosystem services (A-G) 2010-2016 was estimated at 4,058,523,057 $€$. In order to ensure proper use of the support policy tools, the State Nature Protection focuses on completion of inventory of the PG habitats database in the SR. From the comprehensive assessment of the production and non-production functions of PG habitats, a request for the revitalization of valley meadows is required to protect the cultural landscape from the consequences of floods and other natural disasters.

\section{Acknowledgement}

This paper is part of results of VEGA project "Impact of the Common Agricultural Policy on the mitigation of income risk in Slovak agriculture and factors determining the level of risk of agricultural companies" (1/0338/18).

\section{References}

BEČVAROVÁ, V. 2008. Přímé platby v Evropském modelu zemědělství. In Acta Universitatis Agriculture et Silviculturae Mendelianae Brunensis, 2008, no. 3, pp. 21-28. ISSN 2011-8516-106. CHRASTINOVÁ, Z. a i. 2010. Ekonomická efektívnost' Slovenského polnohospodárstva a výrobných odvetví, jeho postavenie v národnej ekonomike a inštitucionálne faktory. Štúdia VUEPP, 2010, 101 s. ISBN 978-80-8058-533-4.

CHRASTINOVÁ, Z. a i. 2013. Zhodnotenie úrovne vplyvu zmien ekonomických parametrov na efektívnost' pol'nohospodárskej výroby a jej hlavných výrobkov z pohl'adu podpornej politiky. Bratislava : VUEPP, 2013, 97 s. ISBN 9778-80-8058-589-1.

ĎURIČOVÁ, I. 2014. Podporná politika do polnohospodárstva SR v rokoch 2004-2012. In Ekonomika polnohospodárstva [online], roč. 14, 2014, č. 2. ISSN 1338-6336.

HOLÚBEK, I. - LOŽEK, O. 2014. Bilancia živín a ekonomická efektívnost' hnojnia lúka a pasienkov. Nitra : SPU, 2014, 65 s. ISBN 978-80-552-1206-6.

HOLÚBEK, R. - JANČOVIČ, J. - GREGOROVÁ, H. - NOVÁK, J. ĎURKOVÁ, E. - VOZÁR, L'. 2007. Krmovinárstvo - Manažment pestovania a využívania krmovín. Nitra : SPU, 2007, 419 s. ISBN 978-80-8069-911-6.

HÖNIGOVÁ, I. - VAČKÁŘ, D. - LORENCOVÁ, E. - MELICHAR, J. GÖTZL, M. - SONDEREGGER, G. - OUŠKOVÁ, V. - HOŠEK. - CHOBOT, K. 2012. Survey on grassland ecosytem services. Report to the EEAEuropean Topic Centre on Boiological Diversity. Prague : Nature Conservation Agency of the Czech Republic, 2012, p. 78.

KOVÁČ, K. - SABO, P. 2001. Agroenvironmentálny program pre SR. SPU : Nitra, 2001, $100 \mathrm{s.}$

KRAJČOVIČ, V. a i. 1968. Krmovinárstvo. Bratislava : SVPL, 1968, $564 \mathrm{~s}$.

LEHMANN, B. - HEDIGER, W. 2004. The conttribution of Grassland to social benefits of agriculture an aconomic analysis. In $20^{\text {th }}$ meet EGF Lucern, Switzerland, 2004, pp. 115-116.

MIDRIAK, R. a i. 2011. Spustnutie pôdy a krajina Slovenska. Banská Bystrica : UMB. ISBN 978-80-557-01010-3.

PLANTUREUX, S. - BERNUÉS, A. - HUGUENIN-ELIE, O. - HOVSTAD, K. - ISSLSTEIN, J. - MCCRACKEN, D. THEROND, O. - VACKAR, D. 2016. Ecosystem service indicators for grassland in relation to ecoclimatic region and land use systems. In Grassland Science in Europe, vol. 21, 2016. 
POLÁK, P. - SAKSA, A. 2005. Priaznivý stav druhov a biotopov Európskeho významu. Banská Bystrica : ŠOP SR, 2005, 736 s.

RUŽIČKOVÁ, H. - KALIVODA, H. 2007. Kvetnaté lúky. Prírodné bohatstvo SR. Bratislava : Veda, 2007, 136 + $48 \mathrm{~s}$.

RYCHNOVSKÁ, M. a i. 1985. Ekologie lučních porostů. Praha : Academia, ČSAV, 1985, $291 \mathrm{~s}$.

VALACHOVIČ, M. - GALVÁNEK, I. 2005. Manažmentové opatrenia pre zachovanie priaznivého stavu Európsky významných nelesných biotopov. In Priaznivý stav biotopov a druhov Európskeho významu, Banská Bystrica, ŠOP SR, 2005, 736 s.
VUEPP. 2015. Správa o polnohospodárstve a potravinárstve SR 2015 (Zelená správa 2016). Národné pol'nohospodárske centrum :VUEPP, 2015. ISBN 978-80-8058-612-6.

VÝSKUMNÝ ÚSTAV zemědělskej techniky Praha-Ruzyně. 2018 [online]. [Retrieved 2018-01-21]. Retrieved from: http://www.vuzt. cz/index.php?l=A35 